\title{
Transpiration in an oil palm landscape: effects of palm age
}

\author{
A. Röll ${ }^{1, *}$, F. Niu ${ }^{1, *}$, A. Meijide ${ }^{2}$, A. Hardanto ${ }^{1,3}$, Hendrayanto ${ }^{4}$, A. Knohl ${ }^{2}$, and D. Hölscher ${ }^{1}$ \\ ${ }^{1}$ Tropical Silviculture and Forest Ecology, Georg-August-Universität Göttingen, Göttingen, Germany \\ ${ }^{2}$ Bioclimatology, Georg-August-Universität Göttingen, Göttingen, Germany \\ ${ }^{3}$ Department of Agricultural Engineering, Universitas Jenderal Soedirman, Purwokerto, Indonesia \\ ${ }^{4}$ Department of Forest Management, Institut Pertanian Bogor, Bogor, Indonesia \\ *These authors contributed equally to this work.
}

Correspondence to: A. Röll (aroell@gwdg.de)

Received: 28 April 2015 - Published in Biogeosciences Discuss.: 19 June 2015

Accepted: 5 September 2015 - Published: 5 October 2015

\begin{abstract}
Oil palm (Elaeis guineensis Jacq.) plantations cover large and continuously increasing areas of humid tropical lowlands. Landscapes dominated by oil palms usually consist of a mosaic of mono-cultural, homogeneous stands of varying age, which may be heterogeneous in their water use characteristics. However, studies on the water use characteristics of oil palms are still at an early stage and there is a lack of knowledge on how oil palm expansion will affect the major components of the hydrological cycle. To provide first insights into hydrological landscape-level consequences of oil palm cultivation, we derived transpiration rates of oil palms in stands of varying age, estimated the contribution of palm transpiration to evapotranspiration, and analyzed the influence of fluctuations in environmental variables on oil palm water use. We studied 15 two- to 25 -year old stands in the lowlands of Jambi, Indonesia. A sap flux technique with an oil palm specific calibration and sampling scheme was used to derive leaf-, palm- and stand-level water use rates in all stands under comparable environmental conditions. Additionally, in a two- and a 12-year old stand, eddy covariance measurements were conducted to derive evapotranspiration rates. Water use rates per leaf and palm increased 5-fold from an age of 2 years to a stand age of approx. 10 years and then remained relatively constant. A similar trend was visible, but less pronounced, for estimated stand transpiration rates of oil palms; they varied 12-fold, from $0.2 \mathrm{~mm} \mathrm{day}^{-1}$ in a 2-year old to $2.5 \mathrm{~mm} \mathrm{day}^{-1}$ in a 12 -year old stand, showing particularly high variability in transpiration rates among medium-aged stands. Comparing sap flux and eddy-covariance derived water fluxes suggests that transpiration contributed $8 \%$ to evapotranspiration in the 2-year
\end{abstract}

old stand and $53 \%$ in the 12-year old stand, indicating variable and substantial additional sources of evaporation, e.g., from the soil, the ground vegetation and from trunk epiphytes. Diurnally, oil palm transpiration rates were characterized by an early peak between 10 and 11 a.m.; there was a pronounced hysteresis in the leaf water use response to changes in vapor pressure deficit for all palms of advanced age. On the day-to-day basis this resulted in a relatively low variability of oil palm water use regardless of fluctuations in vapor pressure deficit and radiation. We conclude that oil palm dominated landscapes show some spatial variations in (evapo)transpiration rates, e.g., due to varying age-structures, but that the temporal variability of oil palm transpiration is rather low. The stand transpiration of some of the studied oil palm stands was as high or even higher than values reported for different tropical forests, indicating a high water use of oil palms under yet to be explained site or management conditions. Our study provides first insights into the eco-hydrological characteristics of oil palms as well as a first estimate of oil palm water use across a gradient of plantation age. It sheds first light on some of the hydrological consequences of the continuing expansion of oil palm plantations.

\section{Introduction}

Oil palm (Elaeis guineensis Jacq.) has become the most rapidly expanding crop in tropical countries over the past few decades, particularly in South East Asia (FAO, 2014). Asides from losses of biodiversity and associated ecosystem functioning (e.g., Barnes et al., 2014), potentially negative con- 
sequences of the expansion of oil palm cultivation on components of the hydrological cycle have been reported (e.g., Banabas et al., 2008). Only a few studies have dealt with the water use characteristics of oil palms so far (Comte et al., 2012). Available evapotranspiration estimates derived from micrometeorological or catchment-based approaches range from 1.3 to $6.5 \mathrm{~mm} \mathrm{day}^{-1}$ for different tropical locations and climatic conditions (e.g., Radersma and Ridder, 1996; Henson and Harun, 2005). However, various components of the water cycle under oil palm remain to be studied for a convincing hydrological assessment of the hydrological consequences of oil palm expansion, e.g., regarding the partitioning of the central water flux of evapotranspiration into transpirational and evaporative fluxes.

Landscapes dominated by oil palms are not necessarily homogeneous in their water use characteristics. Oil palms are usually planted in mono-specific and even-aged stands; commonly, stands are cleared and replanted at an age of approx. 25 years due to difficulties in harvesting operations, potentially declining yields and the opportunity to plant higher yielding varieties of oil palm. This creates a mosaic of stands of varying ages, and hence with possibly different hydrological characteristics.

Substantial differences in transpiration rates of dicot tree stands have been shown for stands of varying age in several studies (e.g., Jayasuriya et al., 1993; Roberts et al., 2001; Vertessy et al., 2001; Delzon and Loustau, 2005); commonly, water use increases rapidly after stand establishment, reaching a peak after some decades (which is associated with high stand productivity and high stand densities) before declining more or less consistently with increasing age. This has, e.g., been demonstrated for Eucalyptus regnans F. Muell. (Cornich and Vertessy, 2001), Eucalyptus sieberi L. Johnson (Roberts et al., 2001) and Pinus pinaster Aiton (Delzon and Loustau, 2005) for stands between 10- and 160-years old. Declines in transpiration rates in older stands were mainly explained by decreasing leaf and sapwood area with increasing stand age (Roberts et al., 2001; Vertessy et al., 2001; Delzon and Loustau, 2005). This may not be the case in palms, as at least at the individual level, for two Amazonian palm species (Iriartea deltoidea Ruiz and Pav. and Mauritia flexu$o s a \mathrm{~L}$.) linear increases of water use with increasing height, and hence age, have been demonstrated (Renninger et al., 2009, 2010).

Water use patterns over a gradient of plantation age to our knowledge have not yet been studied for oil palms. Water use could increase or decline with increasing stand age or could remain relatively stable from a certain age. Reasons for declining water use at a certain age include decreasing functionality of trunk xylem tissue with increasing age due to the absence of secondary growth in monocot species (Zimmermann, 1973), a variety of other hydraulic limitations (see review of dicot tree studies in Ryan et al., 2006) and increased hydraulic resistance due to increased pathway length with increasing trunk height (Yoder et al., 1994). However, for Mexican fan palms (Washingtonia robusta Linden ex André $\mathrm{H}$ Wendl.), no evidence of increasing hydraulic limitations with increasing palm height was found (Renninger et al., 2009). Reasons for potentially increasing water use in older plantations, e.g., include linearly increasing oil palm trunk height with increasing palm age (Henson and Dolmat, 2003). As trunk height and thus volume increase, internal water storages probably also increase, possibly enabling larger (i.e., older) oil palms to transpire at higher rates (Goldstein et al., 1998; Madurapperuma et al., 2009). Additionally, increased stand canopy height is expected to result in an enhanced turbulent energy exchange with the atmosphere, i.e., a closer coupling of transpiration to environmental drivers, which can facilitate higher transpiration rates under optimal environmental conditions (Hollinger et al., 1994; Vanclay, 2009). The mentioned reasons for possibly increasing and decreasing water use with increasing plantations age, respectively, could also partly outbalance each other, or could be outbalanced by external factors (e.g., management related), potentially leading to relatively constant oil palm transpiration with increasing plantation age.

To investigate the water use characteristics of oil palm stands of varying age, we derived leaf-, palm- and stand-scale transpiration estimates from sap flux density measurements with thermal dissipation probes (TDP; Granier, 1985) in 15 different stands (2-25-years old) in the lowlands of Jambi, Sumatra, Indonesia. We used the oil palm specific calibration equation and field measurement scheme recently proposed by Niu et al. (2015). Additionally, in two of these stands (2- and 12-years old) we used the eddy covariance technique (Baldocchi, 2003) to derive independent estimates of evapotranspiration rates. For comparative purposes, the measurements were conducted under similar environmental conditions and partly simultaneously. Our objectives were (1) to derive transpiration rates of oil palms in stands of varying age, (2) to estimate the contribution of palm transpiration to total evapotranspiration, and (3) to analyze the influence of micro-meteorological drivers on oil palm water use. The study provides some first insights into the eco-hydrological characteristics of oil palms at varying spatial (i.e., from leaf to stand) and temporal (i.e., from hourly to daily) scales as well as first estimates of oil palm stand transpiration rates and their contribution to total evapotranspiration. It assesses some of the potential hydrological consequences of oil palm expansion on main components of the water cycle at the stand level.

\section{Methods}

\subsection{Study sites}

The field study was conducted in Jambi, Sumatra, Indonesia (Fig. 1). Between 1991 and 2011, average annual temperature in the region was $26.7 \pm 0.2^{\circ} \mathrm{C}$ (1991-2011 

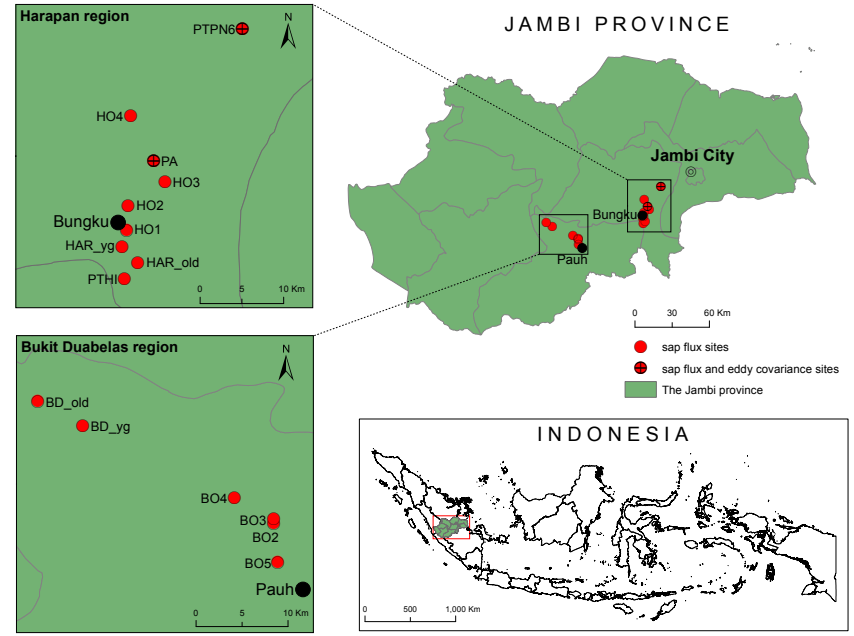

Figure 1. Locations of the studied oil palm stands in Jambi province, Sumatra, Indonesia.

mean $\pm \mathrm{SD}$ ), with little intra-annual variation. Annual precipitation was $2235 \pm 385 \mathrm{~mm}$, a dry season with less than $120 \mathrm{~mm}$ monthly precipitation usually occurred between June and September. However, the magnitude of dry season rainfall patterns varied highly between years (data from Airport Sultan Thaha in Jambi). Soil types in the research region are mainly sandy and clay Acrisols (Allen et al., 2015). We had research plots in a total of 15 different oil palm stands (Table 1), 13 of which were small holder plantations and two of which were properties of big companies. The stands were spread over two landscapes in the Jambi province (i.e., the Harapan and Bukit Duabelas regions, Fig. 1), were all at similar altitude $(60 \mathrm{~m} \pm 15 \mathrm{~m}$ a.s.l.) and belonged to the larger experimental set-up of the CRC990 (www.uni-goettingen. de/crc990, Drescher et al., 2015). Stand age ranged from 2 to 25 years. Management intensity and frequency (i.e., fertilizer and herbicide application, manual and chemical weeding of ground vegetation and clearing of trunk epiphytes) varied considerably among the examined oil palm stands, but both were generally higher in larger plantations, particularly in PTPN6.

\subsection{Sap flux measurements and transpiration}

Following a methodological approach for sap flux measurements on oil palms (Niu et al., 2015), we installed thermal dissipation probe (TDP, Granier, 1985; Uniwerkstätten Universität Kassel, Germany; see Niu et al., 2015 for technical specifications) sensors in the leaf petioles of 16 leaves, four each on four different palms, for each of the 15 examined stands. Insulative materials and aluminum foil shielded the sensors to minimize temperature gradients and reflect radiation. Durable plastic foil was added for protection from rain. The sensors were connected to AM16/32 multiplexers connected to a CR1000 data logger (both Campbell Scien-

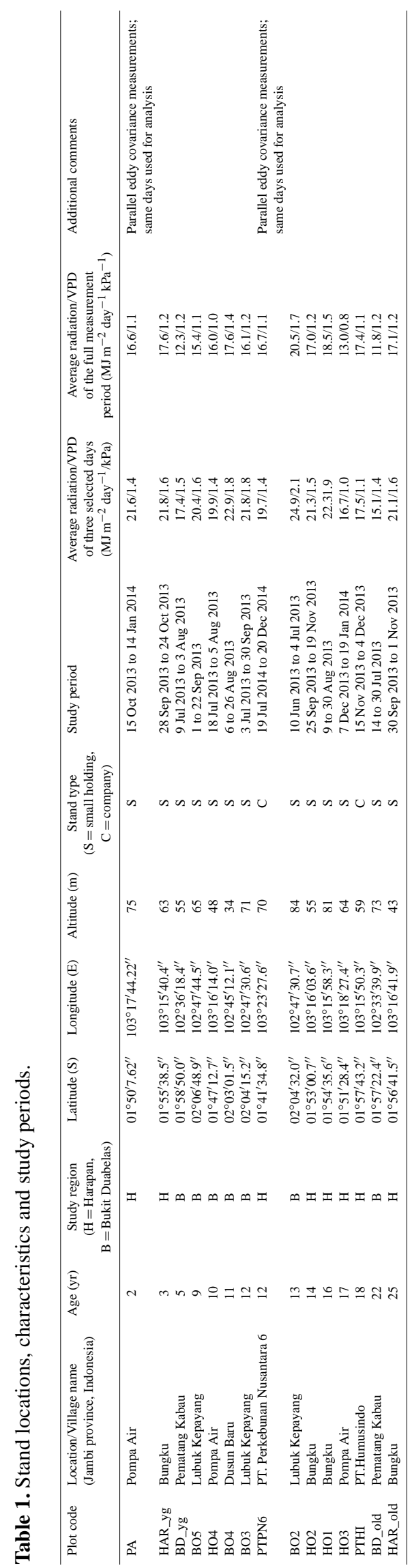

Biogeosciences, 12, 5619-5633, 2015 
tific Inc., Logan, USA). The signals from the sensors were recorded every $30 \mathrm{~s}$ and averaged and stored every $10 \mathrm{~min}$. The $\mathrm{mV}$-data from the logger was converted to sap flux density $\left(\mathrm{g} \mathrm{cm}^{-2} \mathrm{~h}^{-1}\right)$ with the empirically derived calibration equation by Granier (1985), but with a set of equation parameters $a$ and $b$ that was specifically derived for TDP measurements on oil palm leaf petioles (Niu et al., 2015).

Individual leaf water use rates were calculated by multiplying respective sap flux densities (e.g., hourly averages, day sums) by the water conductive areas of the leaves; the water use values of all individual leaves measured simultaneously (min. 13 leaves) were averaged $\left(\mathrm{kg} \mathrm{day}^{-1}\right)$. To scale up to average palm water use $\left(\mathrm{kg} \mathrm{day}^{-1}\right)$, average leaf water use rates were multiplied by the average number of leaves per palm. Multiplying the average palm water use by the number of palms per unit of land $\left(\mathrm{m}^{2}\right)$ yielded stand transpiration rates $\left(T ; \mathrm{mm} \mathrm{day}^{-1}\right)$.

The sap flux measurements were conducted between April 2013 and December 2014, for a minimum of 3 weeks per study plot (Table 1). Three of the plots (BO3, PA, and PTPN6) ran over several months, partly in parallel to other plots. Most measurements, however, were conducted successively and thus partly took place under varying weather conditions. Thus, to minimize day-to-day variability introduced by varying weather for the analysis of effects of stand age on water use at different spatial scales, we used the average of three comparably sunny and dry days from the measurement period of each stand. Exploratory analyses had shown that unexplained variability was lower on sunny days than, e.g., on cloudy or intermediate days or when using the averages of the full respective measurement periods. We chose days with a daily integrated radiation of more than $17 \mathrm{MJ} \mathrm{m}^{-2}$ day $^{-1}$ and an average daytime VPD of more than $1.1 \mathrm{kPa}$; respective averages (mean $\pm \mathrm{SD}$ ) of all days included in the analysis were $20.3 \pm 2.6 \mathrm{MJ} \mathrm{m}^{-2} \mathrm{day}^{-1}$ and $1.6 \pm 0.3 \mathrm{kPa}$ (also see Table 1).

\subsection{Stand structural characteristics}

For all sample leaves, the leaf petiole baseline length was measured between upper and lower probe of each TDP sensor installed in the field; this allowed calculating the water conductive area of each leaf (Niu et al., 2015). For each sample palm, trunk height to the youngest leaf $(\mathrm{m})$ and diameter at breast height $(\mathrm{cm})$ were measured (see Kotowska et al., 2015 for detailed methodology) and the number of leaves per palm was counted. Over time, new leaves emerged and old ones were pruned by the farmers; we assumed the number of leaves per palm to be constant over our measurement period. On the stand level, we counted the number of palms per hectare.

\subsection{Eddy covariance measurements and evapotranspiration}

The eddy covariance technique (Baldocchi, 2003) was used to measure evapotranspiration $\left(E_{T}, \mathrm{~mm} \mathrm{day}^{-1}\right)$ in two of the 15 oil palm stands, the 2-year old (PA) and the 12year old (PTPN6) stand (Table 1). Towers of 7 and $22 \mathrm{~m}$ in height, respectively, were equipped with a sonic anemometer (Metek uSonic-3 Scientific, Elmshorn, Germany) to measure the three components of the wind vector, and an open path carbon dioxide and water analyzer (Li-7500A, Licor Inc., Lincoln, USA) to derive evapotranspiration rates (Meijide et al., 2015). Fluxes were calculated with the software EddyPro (Licor Inc), planar-fit coordinate rotated, corrected for air density fluctuation and quality controlled. Thirty-minute flux data were flagged for quality applying the steady state and integral turbulence characteristic tests (Mauder and Foken, 2006). Data were also filtered according to friction velocity to avoid the possible underestimation of fluxes in stable atmospheric conditions. Due to the amount of data gaps created by lack of power and instrument failure, in the 2-year old plantation we calculated the energy balance closure for the selected three sunny days included in the analysis (see Table 1), for which it was $82 \%$. In the 12 -year old stand, the energy balance closure for the respective full measurement period (May 2014 to February 2015) was $84 \%$. We selected days when most of the 30-min measurements during the day where available. When a single 30 -min value was missing, the value was filled by linear interpolation between the previous and the next 30 min value. Measurements were conducted between July 2013 and February 2014 in the 2year old and from May 2014 to February 2015 in the 12-year old stand. For the analysis, we used the average of the same three sunny days that were selected for the sap flux analysis in the respective plots (see Table 1). Daytime (6 a.m. to 7 p.m.) evapotranspiration rates were used for the analyses and comparison to transpiration rates in order to avoid possible measurement errors as a consequence of low turbulent conditions during nighttime hours.

To estimate the contribution of stand transpiration to total evapotranspiration, we confronted sap flux derived transpiration rates with eddy covariance derived evapotranspiration rates. As described in Niu et al. (2015), our methodological approach for estimating transpiration is associated with sample size-related measurement errors of about $14 \%$. The eddy covariance measurements were carried out in carefully chosen and well-suited locations and focused on daytime observations only, when estimation uncertainties are commonly low ( $<30 \%$, Richardson et al., 2006). The observed differences between evapotranspiration and transpiration estimates presented in this study are thus likely largely due to natural rather than methodological reasons. 


\subsection{Environmental drivers of oil palm water use}

A total of three micrometeorological stations were set up in proximity to the oil palm stands in both landscapes; for the analysis of the water use characteristics of the respective stands, we used the micrometeorological data from the closest available station, at a maximum distance of approx. 15 $\mathrm{km}$ and at similar altitude $(60 \mathrm{~m} \pm 15 \mathrm{~m}$ a.s.l. $)$. The stations were placed in open terrains. Air temperature and relative humidity were measured at a height of $2 \mathrm{~m}$ with a Thermohygrometer (type 1.1025.55.000, Thies Clima, Göttingen, Germany) to calculate vapor pressure deficit (VPD, kPa). A short wave radiation sensor (CMP3 Pyranometer, spectral range 300-2800 nm, Kipp \& Zonen, Delf, the Netherlands) was installed at a height of $3 \mathrm{~m}$, the latter to measure global radiation $\left(R_{\mathrm{g}}, \mathrm{MJ} \mathrm{m}^{-2} \mathrm{day}^{-1}\right.$, from here on referred to as "radiation"). Measurements were taken every $15 \mathrm{~s}$ and averaged and stored on a DL16 Pro data logger (Thies Clima) every $10 \mathrm{~min}$.

The eddy covariance towers (see eddy covariance measurements and evapotranspiration) were also equipped with micrometeorological sensors. Measurements were taken above the canopy, at respective heights of 6.7 and $22 \mathrm{~m}$. Air temperature and humidity (Thermohygrometer, type 1.1025.55.000, Thies Clima), short wave radiation (BF5, Delta-T, Cambridge, United Kingdom) and net radiation (CNR4 Net radiometer, Kipp \& Zonen) were measured every $15 \mathrm{~s}$ and averaged and stored on a DL16 Pro data logger (Thies Clima) every $10 \mathrm{~min}$.

Soil moisture was recorded in the center of eight of the 15 study plots and at the micrometeorological stations and eddy covariance towers. Soil moisture sensors (Trime-Pico 32, IMKO, Ettlingen, Germany) were placed $0.3 \mathrm{~m}$ under the soil surface and connected to a data logger (LogTrans16GPRS, UIT, Dresden, Germany). Data were recorded every hour, for 16 months from June 2013 on. Exploratory analyses showed no significant effects of soil moisture on water use rates (linear regression, $P>0.1$ ). Soil moisture fluctuated only little at the respective locations and during the respective measurement periods and even on a yearly scale, e.g., between $32 \pm 2$ and $38 \pm 2 \%$ between June 2013 and June 2014 (minimum and maximum daily values, mean \pm SE between the three micrometeorological stations). Soil moisture did, e.g., also not fall below $36 \%$ during the measurement period in the long-term monitoring (BO3) stand. It was non-limiting for plant water use. As it showed no significant relationship with water use rates, we omitted soil moisture from further analyses of influences of fluctuations in environmental variables on oil palm water use. Likewise, further recorded micrometeorological variables (e.g., air pressure, wind speed) had no significant relationship with water use rates in our study (linear regression, $P>0.1$ ) and were thus also omitted. We instead focused on the micrometeorological drivers VPD and global radiation; among an array of micrometeorological variables (e.g., also including tempera-
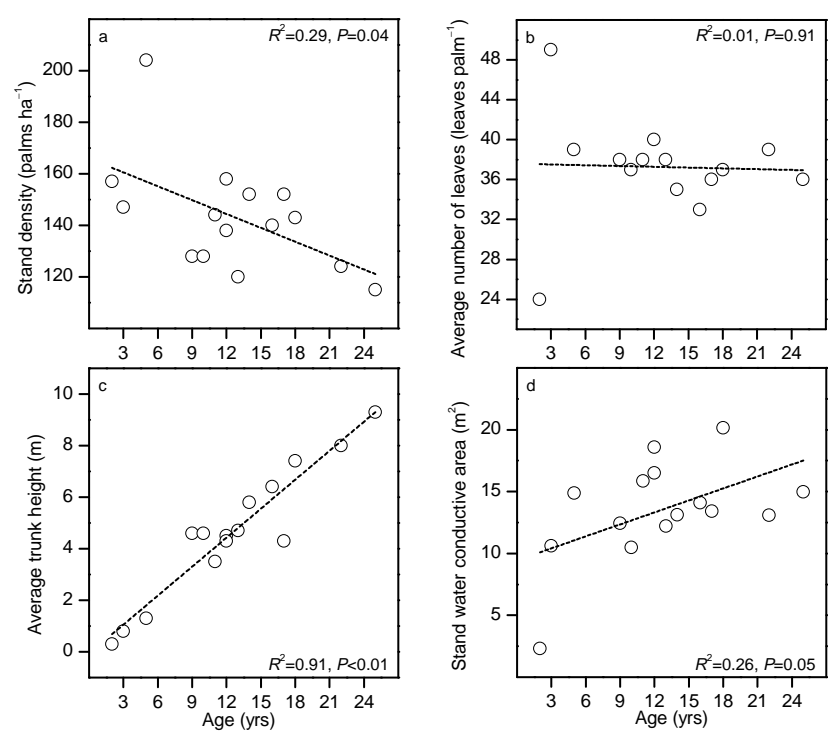

Figure 2. The change of stand density (a), average number of leaves per palm (b), average trunk height (c), and stand water conductive area (d) over age in the 15 studied oil palm stands.

ture, humidity, net radiation) exploratory analysis had shown that they were best suited to explain fluctuations in water use rates. This has also been demonstrated in other studies on plant water use (e.g., Dierick and Hölscher, 2009; Köhler et al., 2009, 2013)

For the diurnal analysis, we averaged the values of three comparably sunny days and normalized VPD and radiation by setting the highest observed hourly rates to one. All statistical analyses and graphing were performed with $\mathrm{R}$ version 3.1.1 (R Core Development team, 2014) and Origin 8.5 (Origin Lab, Northampton, MA, USA).

\section{Results}

\subsection{Stand characteristics}

The number of palms per unit of land linearly decreased with increasing stand age $\left(R^{2}=0.29, P=0.04\right.$; Fig. 2a). The number of leaves per palm remained constant and varied little (32-40 leaves per palm) over stand age (Fig. 2b). The trunk height of oil palms (Fig. 2c) increased linearly with increasing age $\left(R^{2}=0.91, P<0.01\right)$, from about $2 \mathrm{~m}$ at an age of 6 to about $9 \mathrm{~m}$ at an age of 25 years. The average baseline length of leaf petioles at the location of sensor installation increased linearly with stand age $\left(R^{2}=0.65, P<0.01\right)$. As the number of leaves was constant in mature stands, the increasing baseline lengths of leaf petioles resulted in a significant linear increase of the water conductive area per palm with increasing stand age $\left(R^{2}=0.53, P<0.01\right)$. In consequence, the stand-level water conductive area also linearly increased with stand age $\left(R^{2}=0.26, P=0.05\right.$; Fig. $\left.2 \mathrm{~d}\right)$. 


\subsection{Transpiration and evapotranspiration}

Maximum sap flux densities on three sunny days as measured in the leaf petioles of oil palms were variable but did not show a significant trend over age among the examined stands (Fig. 3a). Converted to leaf water use, a clear nonlinear trend over stand age became apparent $\left(R^{2} \mathrm{adj}=0.61\right.$, $P<0.01$ for the Hill function, see Morgan et al., 1975, fit shown in Appendix Fig. 1b, not shown in Fig. 3b): Leaf water use increased 5-fold from a 2-year old stand to a plot age of about 10 years; it then remained relatively constant with further increasing age. At the palm level (Fig. 3c), water use rates closely resemble the relationship of leaf water use and stand age. At the stand level, oil palm transpiration was very low $\left(0.2 \mathrm{~mm} \mathrm{day}^{-1}\right)$ in the 2-year old stand and increased almost 8 -fold until a stand age of 5 years. It then remained relatively constant with increasing age at around $1.3 \mathrm{~mm} \mathrm{day}^{-1}$ (Fig. 3d). However, three medium-aged stands (PTPN6, BO5, and HO2) that showed increased sap flux densities and leaf and palm water use rates also had higher stand transpiration rates, between 2.0 and $2.5 \mathrm{~mm} \mathrm{day}^{-1}$. Potentially, this could be related to differences in radiation on the respective three sunny days that were chosen for the analysis. However, there was no significant relationship between average water use rates on the respective three sunny days in the 15 stands and the respective average radiation (or VPD) on those days (linear regression, $P>0.05$ ), i.e., observed variability in transpiration among the 15 stands could not be explained by differences in weather conditions. A further analysis of the water use rates of eight medium-aged stands with highly variable transpiration rates also gave no indications of variability being induced by differences in radiation. As for the leaf- and palm-level water use rates, a Hill function explained the relationship between stand transpiration and stand age $\left(R^{2}\right.$ adj $=0.45, P<0.01$, Appendix Fig. 1d), but the observed scatter was high, particularly among medium-aged plantations. Overall, stand transpiration rates increased linearly with increasing stand water conductive area $\left(R^{2}=0.42, P=0.01\right)$. On the palm level, there was a linear relationship between water use and trunk height $\left(R^{2}=0.32, P=0.03\right)$, but stand transpiration did not have a linear relationship with average stand trunk height due to decreasing stand densities with increasing stand age; instead, as for transpirations vs. stand age, a Hill function explained the relationship between transpiration and stand trunk height best $\left(R^{2}\right.$ adj $\left.=0.44, P<0.01\right)$ (also see summary in Table 2 ).

On comparably sunny days, the stand-level transpiration among the 15 oil palm stands varied 12-fold, from $0.2 \mathrm{~mm} \mathrm{day}^{-1}$ in a 2 -year old to $2.5 \mathrm{~mm} \mathrm{day}^{-1}$ in a 12 -year old stand. A large part of this spatial variability was explained by different stand variables when applying the Hill function. Stand age explained $45 \%$ of the observed spatial variability of stand transpiration (i.e., $R^{2}$ adj $=0.45$ at $P<0.01$, Appendix Fig. 1), and variables correlated to stand age, i.e., by average stand trunk height and by stand water
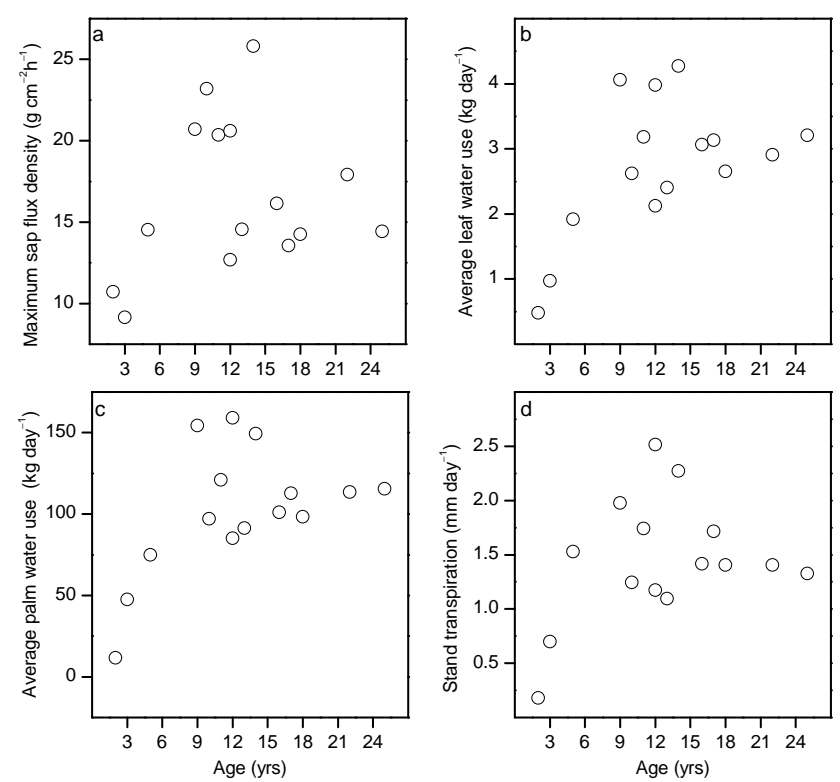

Figure 3. The change of maximum hourly sap flux density (a), average leaf water use (b), average palm water use (c) and stand transpiration (d) over stand age. Data of the different levels derived from simultaneous sap flux measurements on at least 13 leaves per stand; values of three sunny days averaged.

conductive area, explained 44 and $43 \%$, respectively (Table 2). Much of the remaining variability in stand transpiration rates could be explained by varying stand densities (variations of up to $30 \%$ between stands of similar age, see Table 1). Thus, when shifting from the stand level to the palm level, up to $60 \%$ of the spatial variability in palm water use rates could be explained by age and correlated variables (see Fig. $3 \mathrm{c}$ and Table 2). Much of the variability that remains on the palm level is induced by three stands where palm water use was much higher $\left(>150 \mathrm{~kg} \mathrm{day}^{-1}\right)$ than in the other 12 stands $\left(<125 \mathrm{~kg} \mathrm{day}^{-1}\right)$; excluding these three stands from the analysis, $87 \%$ of the spatial variability in palm water use rates could be explained by age (Table 3 ).

Evapotranspiration rates derived from the eddy covariance technique for the 2-year old stand (PA) were $2.8 \mathrm{~mm} \mathrm{day}^{-1}$ (average of three sunny days); the contribution of sap flux derived transpiration was $8 \%$. For the 12year old stand (PTPN6), the evapotranspiration estimate was $4.7 \mathrm{~mm}$ day $^{-1}$; transpiration amounted to about $53 \%$.

\subsection{Drivers of oil palm water use}

Radiation peaked between 12 and 1 p.m. while vapor pressure deficit peaked at around 3 p.m.; the diurnal course of sap flux densities on three sunny days except for the 2-year old stand (PA) showed an early peak of sap flux density (10 to 11 a.m.), which then decreased throughout the rest of the day (Fig. 4a and b, respectively).Thus, there was a varying and partly pronounced hysteresis in the leaf-level response of 
Table 2. Summary table of results for all 15 oil palm stands. $R^{2}$ and $P$ values for linear regression and fitting a Hill function, respectively, are presented to explain variability in water use characteristics (i.e., maximum sap flux density, leaf water use, palm water use and stand transpiration) by the stand variables age, trunk height and sapwood area.

\begin{tabular}{|c|c|c|c|c|c|c|c|c|}
\hline & \multicolumn{2}{|c|}{$\begin{array}{l}\text { Maximum sap } \\
\text { flux density }\end{array}$} & \multicolumn{2}{|c|}{ Leaf water use } & \multicolumn{2}{|c|}{ Palm water use } & \multicolumn{2}{|c|}{$\begin{array}{l}\text { Stand } \\
\text { transpiration }\end{array}$} \\
\hline & Linear fit & Hill function & Linear fit & Hill function & Linear fit & Hill function & Linear fit & Hill function \\
\hline Age & n.s. & $R^{2} \mathrm{adj}=0.16^{* *}$ & $R^{2}=0.31^{*}$ & $R^{2} \mathrm{adj}=0.61^{* *}$ & n.s. & $R^{2} \mathrm{adj}=0.59^{* *}$ & n.s. & $R^{2} \mathrm{adj}=0.45^{* *}$ \\
\hline Trunk height & n.s. & $R^{2} \mathrm{adj}=0.15^{* *}$ & $R^{2}=0.37^{*}$ & $R^{2} \mathrm{adj}=0.62^{* *}$ & $R^{2}=0.32^{*}$ & $R^{2} \mathrm{adj}=0.61^{* *}$ & n.s. & $R^{2} \mathrm{adj}=0.44^{* *}$ \\
\hline Sapwood area & n.s. & $R^{2} \mathrm{adj}=0.02^{* *}$ & $R^{2}=0.41^{* *}$ & $R^{2} \mathrm{adj}=0.60^{* *}$ & $R^{2}=0.39^{* *}$ & $R^{2} \mathrm{adj}=0.61^{* *}$ & $R^{2}=0.42^{* *}$ & $R^{2} \mathrm{adj}=0.43^{* *}$ \\
\hline
\end{tabular}

* For $P \leq 0.05, * *$ for the $P \leq 0.01$, n.s. for no significant relationship $(P>0.05)$.

Table 3. Summary table of results for 12 oil palm stands, i.e., excluding three stands of yet unexplained much higher water use (PTPN6, BO5, and HO2). $R^{2}$ and $P$ values for linear regression and fitting a Hill function, respectively, are presented to explain variability in water use characteristics (i.e., maximum sap flux density, leaf water use, palm water use and stand transpiration) by the stand variables age, trunk height and sapwood area.

\begin{tabular}{|c|c|c|c|c|c|c|c|c|}
\hline & \multicolumn{2}{|c|}{$\begin{array}{l}\text { Maximum sap } \\
\text { flux density }\end{array}$} & \multicolumn{2}{|c|}{ Leaf water use } & \multicolumn{2}{|c|}{ Palm water use } & \multicolumn{2}{|c|}{$\begin{array}{c}\text { Stand } \\
\text { transpiration }\end{array}$} \\
\hline & Linear model & Hill function & Linear model & Hill function & Linear model & Hill function & Linear model & Hill function \\
\hline Age & n.s. & $R^{2} \mathrm{adj}=0.16^{* *}$ & $R^{2}=0.67^{* *}$ & $R^{2} \mathrm{adj}=0.86^{* *}$ & $R^{2}=0.63^{* *}$ & $R^{2} \mathrm{adj}=0.87^{* *}$ & n.s. & $R^{2} \mathrm{adj}=0.75^{* *}$ \\
\hline Trunk height & n.s. & $R^{2} \mathrm{adj}=0.13^{* *}$ & $R^{2}=0.60^{* *}$ & $R^{2}$ adj $=0.82^{* *}$ & $R^{2}=0.56^{* *}$ & $R^{2} \mathrm{adj}=0.86^{* *}$ & & $R^{2} \mathrm{adj}=0.77^{* *}$ \\
\hline Sapwood area & n.s. & $R^{2} \mathrm{adj}=0.01^{* *}$ & $R^{2}=0.68^{* *}$ & $R^{2} \mathrm{adj}=0.80^{* *}$ & $R^{2}=0.64^{* *}$ & $R^{2} \mathrm{adj}=0.85^{* *}$ & $R^{2}=0.61^{* *}$ & $R^{2} \mathrm{adj}=0.69^{* *}$ \\
\hline
\end{tabular}

${ }^{*}$ For $P \leq 0.05,{ }^{* *}$ for the $P \leq 0.01$, n.s. for no significant relationship $(P>0.05)$.

transpiration to VPD (Fig. 4c). It was small in the 2-year old stand (PA). In contrast, it was very pronounced in the 12-year old PTPN6 stand (high water use, commercial plantation), where a very sensitive increase of water use rates with increasing VPD during the morning hours was observed, reaching a peak in water use rates at only about $60 \%$ of maximum daily VPD. After that, water use rates declined relatively consistently throughout the day, despite further rises in VPD. The same pattern was observed in most of the stands; we present values for the oldest stand (HAR_old, 25 years) and another 12-year old stand (BO3, low water use, smallholder plantation) as further examples. The hysteresis in the transpiration response to radiation (Fig. 4d) was generally less pronounced than for VPD.

The day-to-day behavior of oil palm leaf water use rates to environmental drivers (i.e., VPD, radiation) seemed "buffered", i.e., already relatively low VPD and radiation lead to relatively high water use rates (except for in the 2-year old stand), while even strong increases in VPD and radiation only induced rather small further increases in water use rates (Fig. 5). For the 2-year old stand (PA), leaf water use rates over time were almost constant (about $0.4 \mathrm{~kg} \mathrm{day}^{-1}$ ), regardless of daily environmental conditions. Likewise, the water use rates of the remaining stands were relatively insensitive to increases in VPD, i.e., two-fold increases in VPD only led to 1.1- to 1.2-fold increases in water use rates (Fig. 5). A similarly buffered water use response to radiation was observed for the 12-year old small-holder stand (BO3) and the 25- year old stand (HAR_old), i.e., 1.5- and 1.3-fold increases, respectively, for two-fold increases in radiation. The water use response to fluctuations in radiation of the 12-year old commercial stand (PTPN6) was more sensitive, i.e., two-fold increases in radiation induced 1.8-fold increases in water use rates (Fig. 5). The PTPN6 stand also had the highest absolute water use rates among the studied stands.

\section{Discussion}

\subsection{Oil palm transpiration over age}

Among 13 studied productive oil palm stands (i.e., > 4 years old) stand transpiration rates varied more than two-fold. The observed range $\left(1.1-2.5 \mathrm{~mm}\right.$ day $\left.^{-1}\right)$ compares to transpiration rates derived with similar techniques in a variety of treebased tropical land-use systems, e.g., an Acacia mangium plantation on Borneo ( $2.3 \mathrm{~mm} \mathrm{day}^{-1}$ for stands of relatively low density, Cienciala et al., 2000), cacao monocultures and agroforests with varying shade tree cover on Sulawesi $(0.5$ $2.2 \mathrm{~mm} \mathrm{day}^{-1}$, Köhler et al., 2009, 2013) and reforestation and agroforestry stands on the Philippines and in Panama (0.6-2.5 mm day ${ }^{-1}$, Dierick and Hölscher, 2009; Dierick et al., 2010). The highest observed values for oil palm stands (2.0-2.5 mm day ${ }^{-1}$, PTPN6, BO5, and HO2 stands) compare to or even exceed values reported for tropical forests (1.3-2.6 mm day ${ }^{-1}$; Calder et al., 1986; Becker, 1996; McJannet et al., 2007), suggesting that oil palms can transpire at 

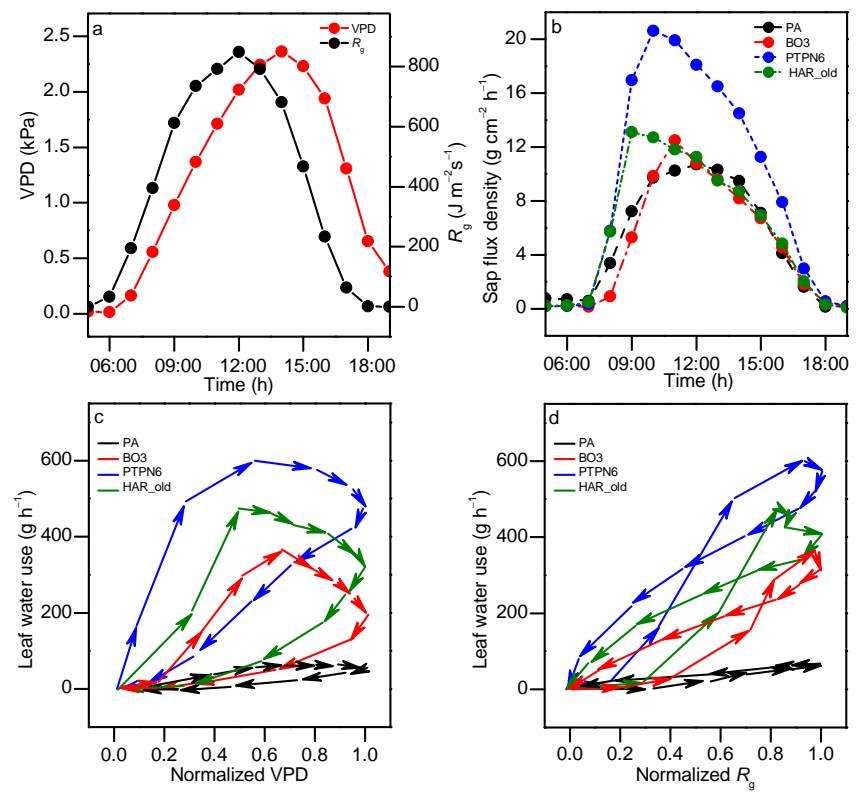

Figure 4. Diurnal course of vapor pressure deficit (VPD) and radiation $\left(R_{\mathrm{g}}\right)$ (a) and of sap flux density in four oil palm stands (b). Leaf water use plotted against hourly averages of normalized VPD (c) and $\mathrm{Rg}$ (d). Average water use estimates based on at least 13 leaves measured simultaneously; average water use rates, VPD and radiation of three sunny days, each point represents one-hourly observation. Data are from the locations PA (2 years old, black arrows), BO3 (12 years old, low water use, red arrows), PTPN6 (12 years old, high water use, blue arrows) and HAR_old (25 years old, green arrows). Data were normalized by setting the maximum to one.
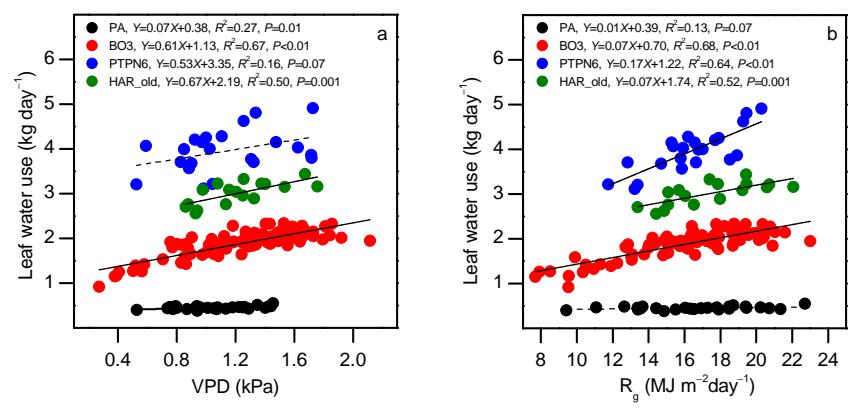

Figure 5. The day-to-day response of leaf water use rates in four different oil palm stands to changes in average daytime vapor pressure deficit (VPD) (a) and integrated daily radiation $\left(R_{\mathrm{g}}\right)(\mathbf{b})$ taken from the closest micrometeorological station from the respective plots. Data of at least 20 days per plot, each point represents 1 day. Leaf water use rates are from the locations PA (2 years old, black circles), BO3 (12 years old, low water use, red circles), PTPN6 (12 years old, high water use, blue circles) and HAR_old (25 years old, green circles). Significant linear relationships are indicated with solid $(P<0.05)$ and dotted $(P<0.1)$ lines, regression functions are provided in the figure. substantial rates under certain, yet unexplained site or management conditions despite, e.g., a much lower biomass per hectare than in natural forests (Kotowska et al., 2015).

In the 15 studied oil palm stands, stand-level transpiration rates increased almost 8 -fold from an age of 2 years to a stand age of 5 years; they then remained relatively constant with further increasing age but were highly variable among productive stands. In our study region, oil palm plantations are commonly cleared and replaced at an age of max. 25-30 years due to constrictions in fruit harvest with further increasing palm height; the oldest studied stand was 25 years old. In contrast to previous studies for dicot tree monocultural stands of varying age we thus did not find, after a relatively early peak, lower stand transpiration rates with increasing stand age (e.g., Jayasuriya et al., 1993; Roberts et al., 2001; Vertessy et al., 2001; Delzon and Loustau, 2005). Asides from the productivity-related artificial short oil palm lifespan in our studied stands as opposed to much larger timescales in studies on tree stands (e.g., comparison of 10- and 91-year old stands in Delzon and Loustau, 2005), this is also related to differences in stand establishment: oil palms are commonly planted in a fixed, relatively large grid, which results in a less pronounced reduction of stand density with increasing stand age than in dicot tree stands, which are often established at much higher stand densities and consequently show higher density-dependent mortality rates. After an initial steep rise of transpiration at a very young plantation age, stand transpiration thus does not seem to vary considerably over the life span of a certain oil palm plantation, which contrasts with the water use characteristics of tree plantations.

The observed substantial stand-to-stand variability of transpiration among the 15 stands, particularly among medium aged plantations, could to $60 \%$ be explained by the variables stand age and density, and up to $87 \%$ when excluding three stands with much higher water use. The remaining unexplained variability as well as the high water use rates in the three mentioned stands could be related to differences in site and soil characteristics. However, all studied stands were located in comparable landscape positions (i.e., upland sites of little or medium inclination) and on similar mineral soils, i.e., loam or clay Acrisols of generally comparable characteristics (Allen et al., 2015; Guillaume et al., 2015). Differences in management intensity could also contribute to the remaining unexplained variability of stand transpiration rates over age. For example, on P-deficient soils such as the Acrisols of our study region (Allen et al., 2015), fertilization can greatly increase oil palm yield (Breure, 1982) and thus total primary productivity, which could consequently lead to a higher water use of oil palms. Accordingly, the highest observed transpiration value in our study came from a stand in an intensively and regularly fertilized, high-yielding commercial plantation. Thus, there may be a trade-off between management intensity, and hence yield, on the one hand, and water use of oil palms on the other hand. This trade-off is of particular interest in the light of the continuing expansion of 
oil palm plantations (FAO, 2014) and increasing reports of water scarcity in oil palm dominated areas (Obidzinski et al., 2012; Larsen et al., 2014)

\subsection{Evapotranspiration and the contribution of transpiration}

Our eddy-covariance derived evapotranspiration estimates of 2.8 and $4.7 \mathrm{~mm} \mathrm{day}^{-1}$ (on sunny days, in 2- and 12-year old stands, respectively) compare very well to the range reported for oil palms in other studies: For 3-4-year old stands in Malaysia, eddy-covariance derived values of 1.3 and 3.3-3.6 mm day ${ }^{-1}$ were reported for the dry and rainy season, respectively (Henson and Harun, 2005). For mature stands, a value of $3.8 \mathrm{~mm} \mathrm{day}^{-1}$ was given, derived by the same technique (Henson, 1999). Micrometeorologically derived values for $4-5$ year-old stands in Peninsular India were $2.0-5.5 \mathrm{~mm} \mathrm{day}^{-1}$ during the dry season (Kallarackal et al., 2004). A catchment-based approach suggested values of 3.3-3.6 mm day ${ }^{-1}$ for stands in Malaysia between 2 and 9 years old (Yusop et al., 2008); evapotranspiration rates derived from the Penman-Monteith equation and published data for various stands were $1.3-2.5 \mathrm{~mm} \mathrm{day}^{-1}$ in the dry season and 3.3-6.5 mm day ${ }^{-1}$ in the rainy season (Radersma and Ridder, 1996). The values reported in most available studies as well as our values overlap in a corridor from about 3 to about $5 \mathrm{~mm} \mathrm{day}^{-1}$; this range compares to evapotranspiration rates reported for rainforests in South East Asia (e.g., Tani et al., 2003a; Kumagai et al., 2005). Considering that oil palm stands, e.g., have much lower stand densities and biomass per hectare than natural tropical forests (Kotowska et al., 2015), this indicates a quite high evapotranspiration from oil palms at both the individual and the stand level. Additionally to the previously discussed relatively high water use of oil palms under certain site or management conditions, the high evapotranspiration from oil palm can be explained by substantial additional water fluxes to the atmosphere. These fluxes (i.e., the differences between evapotranspiration and transpiration estimates) were substantial in both the 2-year old and the 12-year old oil palm stand, i.e., 2.6 and $2.2 \mathrm{~mm} \mathrm{day}^{-1}$, respectively. In the 2-year old PA stand the contribution of palm transpiration to total evapotranspiration was very low ( $8 \%$, Fig. 6). The majority of water fluxes to the atmosphere came from evaporation (e.g., from the soil, interception) and transpiration by other plants. The spaces between palms (planting distance approx. $8 \times 8 \mathrm{~m}$ ) were covered by a dense, up to $50 \mathrm{~cm}$ high grass layer at the time of study (approx. $60 \%$ ground cover); transpiration rates from grasslands can exceed those of forests (e.g., review in McNaughton and Jarvis, 1983; Kelliher et al., 1992) and could well account for $1-2 \mathrm{~mm} \mathrm{day}^{-1}$ to (partly) explain the observed difference of $2.6 \mathrm{~mm}$ day $^{-1}$ between evapotranspiration and transpiration estimates in the PA stand. The 2-year old oil palms were still very small (average trunk height $0.3 \mathrm{~m}$, overall height $1.8 \mathrm{~m}$ ) and had a low average number of leaves, 24 as opposed to $37 \pm 1$ (mean \pm SD) between the 15 studied stands; further, leaves were much smaller than in mature stands. Leaf area index (LAI) of 2-year old oil palm stands was reported be at least 5 -fold lower $(\mathrm{LAI}<1)$ than in mature stands of similar planting density as our study plots (Henson and Dolmat, 2003). The very low observed water use of the oil palms in PA $\left(12 \mathrm{~kg} \mathrm{day}^{-1}\right.$ per palm compared to approx. $100 \mathrm{~kg} \mathrm{day}^{-1}$ per palm in mature stands) and the consequent very low contribution of palm transpiration to evapotranspiration thus do not seem contradictory. At PTPN6 (12 years old) transpiration rates as well as the contribution of transpiration to evapotranspiration (53\%) were much higher than in the 2-year old stand (PA); also, total evapotranspiration was almost $70 \%$ higher. The sum of evaporation (e.g., from the soil) and transpiration by other plants was of similar magnitude ( $2.2 \mathrm{~mm} \mathrm{day}^{-1}$, i.e., $15 \%$ lower) as in PA. Due to the intense management, there was very little ground vegetation in inter-rows present in the PTPN6 stand. However, the abundant trunk epiphytes in butts of pruned leaf petioles that remain on the trunks of mature oil palms may contribute significantly to non-palm transpirational water fluxes. Additionally, oil palm trunks were reported to have a large potential external water storage capacity (up to $6 \mathrm{~mm}$, Merten et al., 2015) for stemflow water after precipitation events; the mentioned butts of pruned leaf petioles constitute "chambers" filled with humus, water and epiphytes, which can remain moist for several days following rainfall events. On dry, sunny days of high evaporative demand, the (partial) drying out of these micro-reservoirs may significantly contribute to water fluxes from evaporation. This is supported by the diurnal course of all water fluxes except oil palm transpiration at PTPN6 (calculated by subtracting hourly transpiration from evapotranspiration rates), which closely followed VPD until its 3 p.m. peak, but then declined rapidly. Generally, our comparison of eddy-covariance derived evapotranspiration and sap-flux derived transpiration suggests significant other water fluxes to the atmosphere than transpiration (e.g., from evaporation) that are still marginal during the morning hours, reach their peak at the time VPD peaks and are extremely sensitive to decreasing VPD in the afternoon. In our study, transpiration amounted to only 8 and $53 \%$ of evapotranspiration in the 2-year old and the 12-year old oil palm stand, respectively, which is lower than values reported, e.g., for mature coconut stands (68\%, Roupsard et al., 2006) and rainforests in Malaysia (81-86\%, Tani et al., 2003b). The low relative contribution of palm transpiration to total evapotranspiration in oil palm stands could be due to relatively high water fluxes from evaporation, e.g., after rainfall interception. Interception was reported to be substantially higher in oil palm stands in the study region ( $28 \%$, Merten et al., 2015) than, e.g., in rainforests in Malaysia (12-16\%, Tani et al., 2003b) and Borneo (18\%, Dykes, 1997). The high water losses from interception paired with the relatively high water use of oil palms and the consequent high total evapotranspirational fluxes from oil palm plantations could con- 

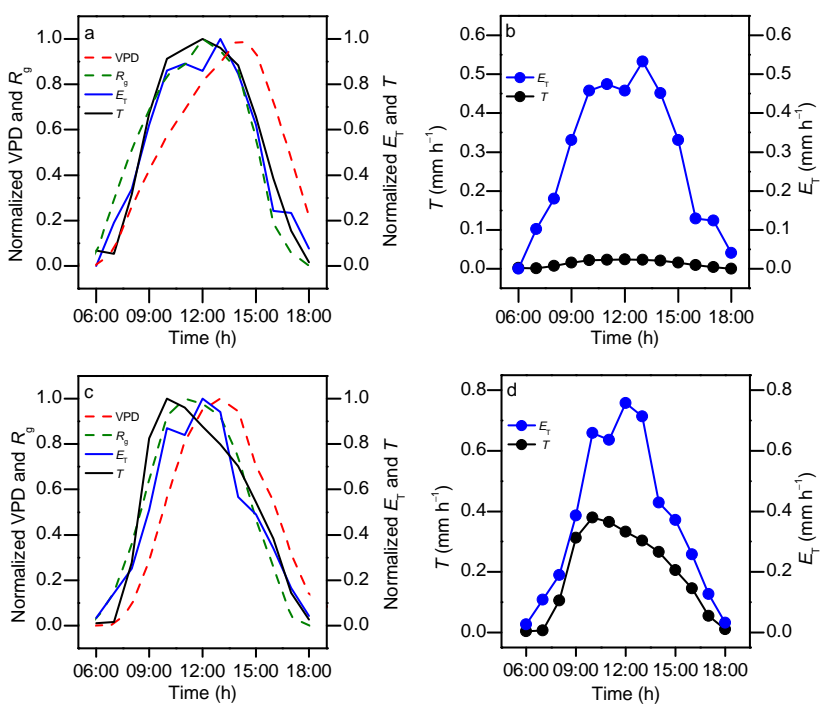

Figure 6. Normalized diurnal pattern of vapor pressure deficit (VPD), radiation $\left(R_{\mathrm{g}}\right)$, transpiration $(T)$ and evapotranspiration $\left(E_{T}\right)$ in a 2-year old (PA) (a) and a 12-year old (PTPN6) (c) oil palm stand; absolute hourly values of $E_{T}$ and $T$ in PA (b) and PTPN6 (d). Eddy covariance and sap flux density measurements were conducted in parallel to derive evapotranspiration and transpiration rates, respectively. Values of three sunny days averaged.

tribute to reduced water availability at the landscape level in oil palm dominated areas, e.g., during pronounced dry periods (Merten et al., 2015).

\subsection{Micro-meteorological drivers of oil palm water use}

At the diurnal scale, we examined the relationship between water use rates and VPD and radiation (hourly averages of three sunny days, Fig. 4): in all examined oil palm stands except the very young stand (PA, 2 years old), under comparable sunny conditions, the intra-daily transpiration response to the mentioned environmental drivers was characterized by an early peak (10-11 a.m.), before radiation (12 a.m.to 1 p.m.) and VPD (2-3 p.m.) peaked; after this early peak of water use rates, however, they subsequently declined consistently throughout the day, regardless of further increases of radiation and VPD (Fig. 4). For most thus far examined dicot tree species, peaks in water use rates coincide with peaks in radiation (e.g., Zeppel et al., 2004; Köhler et al., 2009; Dierick et al., 2010; Horna et al., 2011); however, a similar behavior as in oil palms, i.e., early peaks of transpiration followed by consistent declines, has been reported, but not yet explained, for Acer rubrum L. (Johnson et al., 2011) and some tropical bamboo species (Mei et al., 2015). Due to the early peaks, considerable hysteresis in the oil palm transpiration response to VPD was observed in all examined stands except for PA (2 years old). In studies on tree species, pronounced hysteresis has been reported, e.g., for eucalyptus trees in Australia during the dry season (O'Grady et al., 1999; Zeppel et al., 2004) or for popular hybrids on clear, but not on cloudy days (Meinzer et al., 1997). The underlying eco-hydrological mechanisms remain unexplained; potentially, the development of water stress (Kelliher et al., 1992), decreasing leaf stomatal conductance and assimilation rates over the course of a day (Easmus and Cole, 1997; Williams et al., 1998; Zeppel et al., 2004) or changes in leaf water potential, soil moisture content or xylem sap abscistic acid content (Prior et al., 1997; Thomas et al., 2000; Thomas and Easmus, 2002) could play a role. For oil palms, no eco-physiological studies are available yet to assess these potential underlying reasons for the observed pronounced diurnal transpirational hysteresis. A contribution of stem water storage to transpiration in the morning could be another potential explanation (Waring and Running, 1978; Waring et al., 1979; Goldstein et al., 1998). It could explain the early peak followed by a steady decline of transpiration regardless of VPD and radiation patterns, the decline being the consequence of eventually depleted trunk water storage reservoirs. Other (palm) species were reported to have substantial internal trunk water storage capacities (e.g., Holbrook and Sinclair, 1992; Madurapperuma et al., 2009), which can contribute to sustain relatively high transpiration rates despite limiting environmental conditions (e.g., Vanclay, 2009).

At the day-to-day scale, in all 15 oil palm stands, the response of water use rates particularly to changes in VPD seemed "buffered", i.e., near-maximum daily water use rates were reached at relatively low VPD, but better environmental conditions for transpiration (i.e., higher VPD) did not induce strong increases in water use rates (i.e., 1.2-fold increase in water use for a two-fold increase in VPD). Likewise, for both photosynthesis rates (Dufrene and Saugier, 1993) and water use rates (Niu et al., 2015) of oil palm leaves, linear increases with increasing VPD were reported at relatively low VPD, until a certain threshold $(1.5-1.8 \mathrm{kPa})$ was reached, after which no further increases in photosynthesis and water use rates, respectively, occurred. For tropical tree and bamboo species, more sensitive responses to fluctuations in VPD, i.e., 1.4- to 1.7-fold increases and more than two-fold increases, respectively, have been reported (e.g., Köhler et al., 2009; Dierick et al., 2010; Komatsu et al., 2010). However, a similar "leveling-off" effect of water use rates at higher VPD, as observed for the oil palm stands in our study, has been reported for Moso bamboo stands in Japan (in contrast to coniferous forests in the same region, where water use had a linear relationship with VPD, Komatsu et al., 2010). The hydraulic limitations "buffering" the day-to-day oil palm water use response to VPD are yet to be explained. As soil moisture was non-limiting, they are likely of micrometeorological or ecophysiological nature. The early peaks of water use rates and the consequent strong hysteresis to VPD on the intra-daily level, which may point to a depletion of internal trunk water storage reservoirs early in the day as a possible reason for substantially reduced oil palm water use rates at the time of 
diurnally optimal environmental conditions, give some first indications of the direction that further studies could take.

\section{Conclusions}

The study provides first insights into eco-hydrological characteristics of oil palms at varying spatial and temporal scales and first estimates of oil palm stand transpiration rates across an age gradient. Stand transpiration rates increased almost 8 -fold from an age of 2 years to a stand age of 5 years and then remained constant with further increasing age, but were highly variable among medium-aged plantations. In some of the studied stands, transpiration was quite high, i.e., higher than values reported for some tropical rainforests. There may be a potential trade-off between water use and management intensity of oil palm plantations. Total evapotranspirational water fluxes from a 2- and a 12-year old oil palm plantation were also relatively high, i.e., other water fluxes besides transpiration (e.g., from the soil) contributed substantially and variably to evapotranspiration. This reduced a 12fold difference in transpiration between the two stands to a less than two-fold difference in evapotranspiration. In the diurnal course, most oil palms showed a strong hysteresis between water use and VPD. On the day-to-day basis this results in a relatively low variability of oil palm water use regardless of fluctuations in VPD and radiation. In conclusion, oil palm dominated landscapes show some spatial variations in (evapo)transpiration rates, e.g., due to varying agestructures and stand densities, but the day-to-day variability of oil palm transpiration is rather low. Under certain site or management conditions, (evapo)transpirational water fluxes from oil palms can be substantial.

\section{Data availability}

The underlying data set used in this manuscript is deposited and stored in the EFForTS-IS data base (https://efforts-is. uni-goettingen.de) of the CRC990 of the Georg-AugustUniversität Göttingen, Germany (www.uni-goettingen.de/ crc990). Due to project data sharing agreement restrictions, this data base is not publicly accessible, and digital identifiers and citations can thus not be provided. However, the data are stored safely and according to the guidelines of good practise of data storage as, e.g., demanded by the DFG (German Research Foundation). To additionally make the underlying data of our manuscript accessible for readers, we have attached them as a zipped supplement to this manuscript. Inside the supplement, all data used in this manuscript can be found in the form of $30 \mathrm{~min}$ observations for each of the 15 studied stands. The supplement file names correspond to the plot codes presented in Table 1 . 


\section{Appendix A}
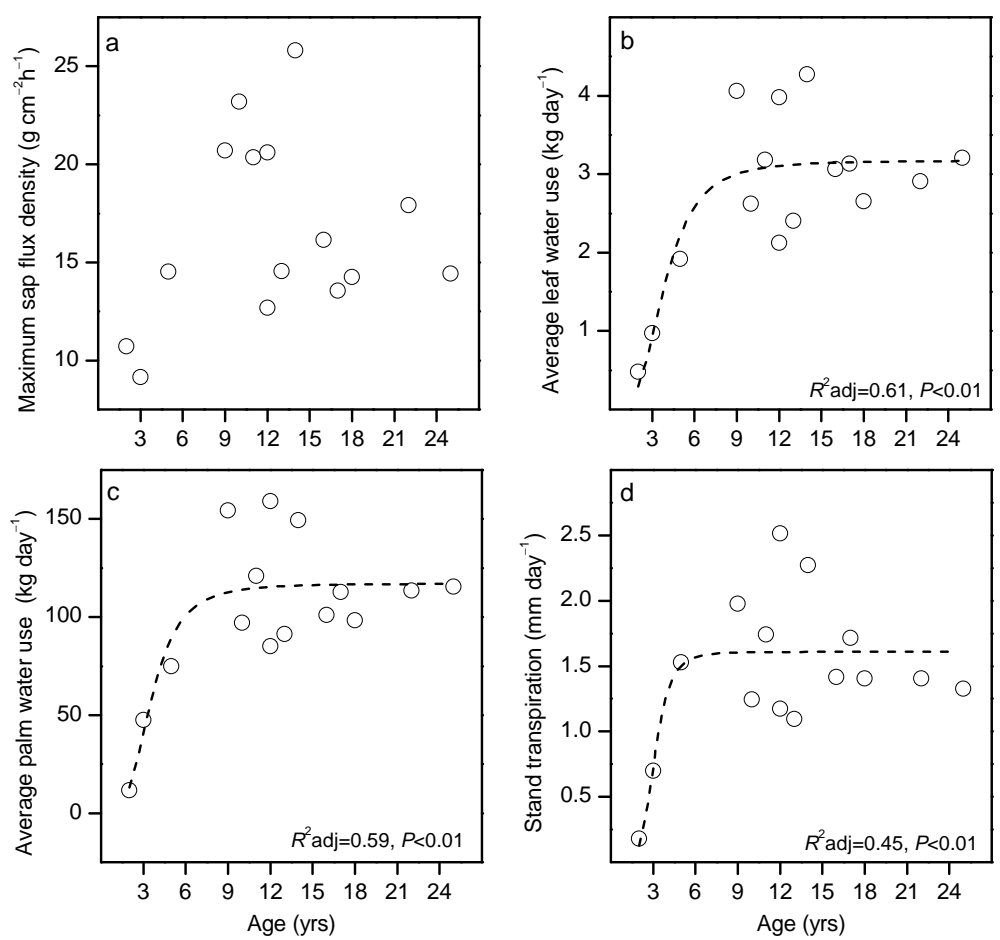

Figure A1. The change of maximum hourly sap flux density (a), average leaf water use (b), average palm water use (c) and stand transpiration (d) over stand age. Data of the different levels derived from simultaneous sap flux measurements on at least 13 leaves per stand; values of three sunny days averaged. The provided fits are Hill functions (dotted lines). 


\section{The Supplement related to this article is available online at doi:10.5194/bg-12-5619-2015-supplement.}

Acknowledgements. This study was supported by a grant from the German Research Foundation (DFG, CRC 990, A02, A03). Furong Niu received a scholarship from the China Scholarship Council (CSC); Afik Hardanto received a scholarship from the Indonesian-German Scholarship Program (IGSP). The authors thank Pak Heri Junedi and Pak Agusta Herdhata for constructive cooperation in the project. The authors also thank Surya Darma Tarigan for data on the external trunk water storage capacity of oil palm trunks, Dodo Gunawan for providing long-term climatic data and Martyna Kotowska for stand structural data. A big "Thank you!" also to everyone in Göttingen, Bogor and Jambi who made this work possible. Terimakasih!

This open-access publication was funded by the University of Göttingen.

Edited by: Y. Kuzyakov

\section{References}

Allen, K., Corre, M., Tjoa, A., and Veldkamp, E.: Soil nitrogencycling response to conversion of lowland forests to oil palm and rubber plantations in Sumatra, Indonesia, PLoS ONE, 10, e0133325, doi:10.1371/journal.pone.0133325, 2015.

Baldocchi, D.: Assessing the eddy covariance technique for evaluating carbon dioxide exchange rates of ecosystems: past, present and future, Glob. Change Biol., 9, 479-492, 2003.

Banabas, M., Turner, M. A., Scotter, D. R., and Nelson, P. N.: Losses of nitrogen fertiliser under oil palm in Papua New Guinea: 1. Water balance, and nitrogen in soil solution and runoff, Aust. J. Soil Res., 46, 332-339, doi:10.1071/SR07171, 2008.

Barnes, A. D., Jochum, M., Mumme, S., Haneda, N. F., Farajallah, A., Widarto, T. H., and Brose, U.: Consequences of tropical land use for multitrophic biodiversity and ecosystem functioning, Nat. Commun., 5, 5351, doi:10.1 038/ncomms6351, 2014.

Becker, P.: Sap flow in Bornean heath and dipterocarp forest trees during wet and dry periods, Tree Physiol., 16, 295-299, doi:10.1093/treephys/16.1-2.295, 1996.

Breure, C. J.: Factors affecting yield and growth of oil palm tenera in West New Britain, Oléagineux, 37, 213-227, 1982.

Calder, I. R., Wright, I. R., and Murdiyarso, D.: A study of evaporation from tropical rain forest-West Java, J. Hydrol., 89, 13-31, doi:10.1016/0022-1694(86)90139-3, 1986.

Cienciala, E., Kučera, J., and Malmer, A.: Tree sap flow and stand transpiration of two Acacia mangium plantations in Sabah, Borneo, J. Hydrol., 236, 109-120, doi:10.1016/S00221694(00)00291-2, 2000.

Comte, I., Colin, F., Whalen, J. K., Grünberger, O., and Caliman, J. P.: Agricultural practices in oil palm plantations and their impact on hydrological changes, nutrient fluxes and water quality in Indonesia, in: Advances in Agronomy Volume 116, Advances in Agronomy, Elsevier, Burlington, 71-124, 2012.
Cornish, P. M. and Vertessy, R. A.: Forest age-induced changes in evapotranspiration and water yield in a eucalypt forest, J. Hydrol., 242, 43-63, doi:10.1016/S0022-1694(00)00384-X, 2001.

Delzon, S. and Loustau, D.: Age-related decline in stand water use: sap flow and transpiration in a pine forest chronosequence, Agr. Forest Meteorol., 129, 105-119, doi:10.1016/j.agrformet.2005.01.002, 2005.

Dierick, D. and Hölscher, D.: Species-specific tree water use characteristics in reforestation stands in the Philippines, Afr. Forest Meteorol., 149, 1317-1326, doi:10.1016/j.agrformet.2009.03.003, 2009.

Dierick, D., Kunert, N., Köhler, M., Schwendenmann, L., and Hölscher, D.: Comparison of tree water use characteristics in reforestation and agroforestry stands across the tropics, in: Tropical Rainforests and Agroforests under Global Change, edited by: Tscharntke, T., Leuschner, C., Veldkamp, E., Faust, H., Guhardja, E., and Bidin, A., Environmental Science and Engineering, Springer Berlin Heidelberg, Berlin, Heidelberg, 293 308, 2010.

Drescher, J., Rembold, K., Allen, K., Faust, H., Jaya, N. S., Knohl, A., Meijide, A., Melati, D., Pérez-Cruzado, C., Steinebach, S., Wiegand, K., Qaim, M., Alamsyah, Z., Basir, M., Basri, Z., Buchori, D., Fauzi, A., Irawan, B., Malarisang, S., Siregar, I. Z., Rauf, A., Tasman, A., Tjoa, A., Zulkarnain, Z., Scheu, S., and Kreft, H.: Ecological and socioeconomic functions of tropical lowland rainforest transformation systems: an integrative approach, Philos. T. R. Soc. B, in review, 2015.

Dufrene, E. and Saugier, B.: Gas exchange of oil palm in relation to light, vapour pressure deficit, temperature and leaf age, Funct. Ecol., 97-104, 1993.

Dykes, A. P.: Rainfall interception from a lowland tropical rainforest in Brunei, J. Hydrol., 200, 260-279, 1997.

Easmus, D. and Cole, S.: Diurnal and seasonal comparisons of assimilation, phyllode conductance and water potential of three Acacia and one Eucalyptus species in the Wet-Dry tropics of Australia, Aust. J. Bot., 45, 275-290, doi:10.1071/BT96020, 1997.

FAO: FAOSTAT online statistical service, Food and Agriculture Organization of the United Nations, Rome, Italy, available at: http://faostat3.fao.org/ (last access: 19 March 2015), 2014.

Goldstein, G., Andrade, J. L., Meinzer, F. C., Holbrook, N. M., Cavelier, J., Jackson, P., and Celis, A.: Stem water storage and diurnal patterns of water use in tropical forest canopy trees, Plant Cell Environ., 21, 397-406, doi:10.1046/j.13653040.1998.00273.x, 1998.

Granier, A.: Une nouvelle méthode pour la mesure du flux de sève brute dans le tronc des arbres, Ann. For. Sci., 42, 193-200, 1985.

Guillaume, T., Muhammad, D., and Kuzyakov, Y.: Losses of soil carbon by conversion of tropical forest to plantations: Erosion and decomposition estimated by $\delta^{13} \mathrm{C}$, Glob. Change Biol., 21, 3548-3560, doi:10.1111/gcb.12907, 2015.

Henson, I. E.: Notes on oil palm productivity. IV. Carbon dioxide gradients and evapotranspiration, above and below the canopy, J. Oil Palm Res., 11, 33-40, 1999.

Henson, I. E. and Dolmat, M. T.: Physiological analysis of an oil palm density trial on a peat soil, J. Oil Palm Res., 15, 1-27, 2003.

Henson, I. E. and Harun, M. H.: The influence of climatic conditions on gas and energy exchanges above a young oil palm stand in north Kedah, J. Oil Palm Res., 17, 73-91, 2005. 
Holbrook, N. M. and Sinclair, T. R.: Water balance in the arborescent palm, Sabal palmetto. II. Transpiration and stem water storage, Plant Cell Environ., 15, 401-409, 1992.

Hollinger, D. Y., Kelliher, F. M., Schulze, E. D., and Köstner, B. M. M.: Coupling of tree transpiration to atmospheric turbulence, Nature, 371, 60-62, doi:10.1038/371060a0, 1994.

Horna, V., Schuldt, B., Brix, S., and Leuschner, C.: Environment and tree size controlling stem sap flux in a perhumid tropical forest of Central Sulawesi, Indonesia, Ann. For. Sci., 68, 10271038, doi:10.1007/s13595-011-0110-2, 2011.

Jayasuriya, M., Dunn, G., Benyon, R., and O'Shaughnessy, P. J.: Some factors affecting water yield from mountain ash (Eucalyptus regnans) dominated forests in south-east Australia, J. Hydrol., 150, 345-367, doi:10.1016/0022-1694(93)90116-Q, 1993.

Johnson, D. M., McCulloh, K. A., Meinzer, F. C., Woodruff, D. R., and Eissenstat, D. M.: Hydraulic patterns and safety margins, from stem to stomata, in three eastern U.S. tree species, Tree Physiol., 31, 659-668, doi:10.1093/treephys/tpr050, 2011.

Kallarackal, J., Jeyakumar, P., and George S. J.: Water use of irrigated oil palm at three different arid locations in Peninsular India, J. Oil Palm Res., 16, 45-53, 2004.

Kelliher, F. M., Köstner, B., Hollinger, D. Y., Byers, J. N., Hunt, J. E., McSeveny, T. M., Meserth, R., Weir, P. L., and Schulze, E. D.: Evaporation, xylem sap flow, and tree transpiration in a New Zealand broad-leaved forest, Agr. Forest Meteorol., 62, 53-73, doi:10.1016/0168-1923(92)90005-O, 1992.

Köhler, M., Dierick, D., Schwendenmann, L., and Hölscher, D.: Water use characteristics of cacao and Gliricidia trees in an agroforest in Central Sulawesi, Indonesia, Ecohydrology, 2, 520-529, doi:10.1002/eco.67, 2009.

Köhler, M., Hanf, A., Barus, H., and Hölscher, D.: Cacao trees under different shade tree shelter: effects on water use, Agr. Syst., 88, 63-73, 2013.

Komatsu, H., Onozawa, Y., Kume, T., Tsuruta, K., Kumagai, T., Shinohara, Y., and Otsuki, K.: Stand-scale transpiration estimates in a Moso bamboo forest: II. Comparison with coniferous forests, Forest Ecol. Manag., 260, 1295-1302, doi:10.1016/j.foreco.2010.06.040, 2010.

Kotowska, M. M., Leuschner, C., Triadiati, T., Meriem, S., and Hertel, D.: Quantifying above- and belowground biomass carbon loss with forest conversion in tropical lowlands of Sumatra (Indonesia), Glob. Change Biol., doi:10.1111/gcb.12979, 2015.

Kumagai, T., Saitoh, T. M., Sato, Y., Takahashi, H., Manfroi, O. J., Morooka, T., Kuraji, K., Suzuki, M., Yasunari, T., and Komatsu, H.: Annual water balance and seasonality of evapotranspiration in a Bornean tropical rainforest, Agr. Forest Meteorol., 128, 8192, doi:10.1016/j.agrformet.2004.08.006, 2005.

Larsen, R. K., Jiwan, N., Rompas, A., Jenito, J., Osbeck, M., and Tarigan, A.: Towards "hybrid accountability" in EU biofuels policy? Community grievances and competing water claims in the Central Kalimantan oil palm sector, Geoforum, 54, 295-305, 2014.

Madurapperuma, W. S., Costa, W. de, Sangakkara, U. R., and Jayasekara, C.: Estimation of water use of mature coconut (Cocos nucifera L.) cultivars (CRIC 60 and CRIC 65) grown in the low country intermediate zone using the compensation heat pulse method (CHPM), J. Natl. Sci. Found. Sri Lanka, 37, 175-186, doi:10.4038/jnsfsr.v37i3.1211, 2009.
Mauder, M. and Foken, T.: Impact of post-field data processing on eddy covariance flux estimates and energy balance closure, Meteorol. Z., 15, 97-609, doi:10.1127/0941-2948/2006/0167, 2006.

McJannet, D., Fitch, P., Disher, M., and Wallace, J.: Measurements of transpiration in four tropical rainforest types of north Queensland, Australia, Hydrol. Process., 21, 3549-3564, doi:10.1002/hyp.6576, 2007.

McNaughton, K. G. and Jarvis, P. G.: Water deficits and plant growth: Predicting effects of vegetation changes on transpiration and evaporation, Academic Press, New York, 1983.

Mei, T., Fang, D., Röll, A., Niu, F., Hendrayanto, and Hölscher, D.: Water use characteristics of four tropical bamboo species derived from sap flux measurements, Front. Plant Sci., in review, 2015.

Meijide, A., Röll, A., Herbst, M., Niu. F., Tiedemann. F., June, T., Rauf. A., Hölscher, D., and Knohl, A.: Water and energy fluxes in oil palm plantations: effect of environmental variables and oil palm age, in preparation, 2015.

Meinzer, F. C., Hinckley, T. M., and Ceulemans, R.: Apparent responses of stomata to transpiration and humidity in a hybrid poplar canopy, Plant Cell Environ., 20, 1301-1308, doi:10.1046/j.1365-3040.1997.d01-18.x, 1997.

Merten, J., Röll, A., Guillaume, T., Meijide, A., Tarigan, S., Agusta, H., Dislich, C., Dittrich, C., Faust, H., Gunawan, D., Hein, J., Hendrayanto, Knohl, A., Kuzyakov, Y., Wiegand, K., and Hölscher, D.: Water scarcity and oil palm expansion: social views and environmental processes, Ecol. Soc., in revision, 2015.

Morgan, P. H., Mercer, L. P., and Flodin, N. W.: General model for nutritional responses of higher organisms, P. Natl. Acad. Sci. USA, 72, 4327-4331, 1975.

Niu, F., Röll, A., Hardanto, A., Meijide, A., Köhler, M., Hendrayanto, and Hölscher, D.: Oil palm water use: calibration a sap flux method and a field measurement of scheme, Tree Physiol., 35, 563-573, doi:10.1093/treephys/tpv013, 2015.

Obidzinski, K., Andriani, R., Komarudin, H., and Andrianto, A.: Environmental and social impacts of oil palm plantations and their implications for biofuel production in Indonesia, Ecol. Soc., 17, 25, doi:10.5751/ES-04775-170125, 2012.

O'Grady, A. P., Eamus, D., and Hutley, L. B.: Transpiration increases during the dry season: patterns of tree water use in eucalypt open-forests of northern Australia, Tree Physiol, 19, 591597, doi:10.1093/treephys/19.9.591, 1999.

Prior, L. D., Eamus, D., and Duff, G. A.: Seasonal trends in carbon assimilation, stomatal conductance, pre-dawn leaf water potential and growth in Terminalia ferdinandiana, a deciduous tree of northern Australian savannas, Aust. J. Bot., 45, 53-69, doi:10.1071/BT96065, 1997.

Radersma, S. and Ridder, N. de: Computed evapotranspiration of annual and perennial crops at different temporal and spatial scales using published parameter values, Agr. Water Manage., 31, 17-34, doi:10.1016/0378-3774(95)01235-4, 1996.

R Core Team R: A language and environment for statistical computing R Foundation for Statistical Computing, Vienna, Austria, 2014.

Renninger, H. J., Phillips, N., and Hodel, D. R.: Comparative hydraulic and anatomic properties in palm trees (Washingtonia robusta) of varying heights: implications for hydraulic limitation to increased height growth, Trees, 23, 911-921, doi:10.1007/s00468-009-0333-0, 2009. 
Renninger, H. J., Phillips, N., and Salvucci, G. D.: Wet- vs. dryseason transpiration in an Amazonian rain forest palm Iriartea deltoidea, Biotropica, 42, 470-478, doi:10.1111/j.17447429.2009.00612.x, 2010.

Richardson, A. D., Hollinger, D. Y., Burba, G. G., Davis, K. J., Flanagan, L. B., Katul, G. G., Munger, J. W., Ricciuto, D. M., Stoy, P. C., Suyker, A. E., Verma, S. B., and Wofsy, S. C.: A multi-site analysis of random error in tower-based measurements of carbon and energy fluxes, Agr. Forest Meteorol., 136, 1-18, doi:10.1016/j.agrformet.2006.01.007, 2006.

Roberts, S., Vertessy, R., and Grayson, R.: Transpiration from $E u$ calyptus sieberi (L. Johnson) forests of different age, Forest Ecol. Manage., 143, 153-161, doi:10.1016/S0378-1127(00)00514-4, 2001.

Roupsard, O., Bonnefond, J. M., Irvine, M., Berbigier, P., Nouvellon, Y., Dauzat, J., Taga, S., Hamel, O., Jourdan, C., SaintAndré, L., Mialet-Serra, I., Labouisse, J. P., Epron, D., Joffre, R., Braconnier, S., Rouzière, A., Navarro, M., and Bouillet, J. P.: Partitioning energy and evapo-transpiration above and below a tropical palm canopy, Agr. Forest Meteorol., 139, 252-268, doi:10.1016/j.agrformet.2006.07.006, 2006.

Ryan, M. G., Phillips, N., and Bond, B. J.: The hydraulic limitation hypothesis revisited, Plant Cell Environ., 29, 367-381, doi:10.1111/j.1365-3040.2005.01478.x, 2006.

Tani, M., Nik, A. R., Ohtani, Y., Yasuda, Y., Sahat, M. M., Kasran, B., Takanashi, S., Noguchi, S., Yusop, Z., and Watanabe, T.: Characteristics of energy exchange and surface conductance of a tropical rain forest in peninsular Malaysia, edited by: Pasoh, Okuda, T., Manokaran, N., Matsumoto, Y., Niiyama, K., Thomas, S. C., Ashton, P. S., Springer, Japan, Tokyo, 73-88, 2003a.

Tani, M., Nik, A. R., Yasuda, Y., Noguchi, S., Shamsuddin, S. A., Sahat, M. M., and Takanashi, S.: Long-term estimation of evapotranspiration from a tropical rain forest in Peninsular Malaysia, in: Water Resources Systems-Water Availability and Global Change, edited by: Franks, S., Bloeschl, G., Kumagai, M., Musiake, K., Rosbjerg, D., IAHS Publ. No. 280, IAHS Press, Wallingford, 267-274, 2003b.

Thomas, D. S., Eamus, D., and Shanahan, S.: Influence of season, drought and xylem ABA on stomatal responses to leaf-toair vapour pressure difference of trees of the Australian wet-dry tropics, Aust. J. Bot., 48, 143-151, doi:10.1071/BT98090, 2000.
Thomas, D. S. and Eamus, D.: Seasonal patterns of xylem sap $\mathrm{pH}$, xylem abscisic acid concentration, leaf water potential and stomatal conductance of six evergreen and deciduous Australian savanna tree species, Aust. J. Bot., 50, 229-236, doi:10.1071/BT01045, 2002.

Vanclay, J. K.: Managing water use from forest plantations, Forest Ecol. Manage., 257, 385-389, doi:10.1016/j.foreco.2008.09.003, 2009.

Vertessy, R. A., Watson, F. G., and O'Sullivan, S. K.: Factors determining relations between stand age and catchment water balance in mountain ash forests, Forest Ecol. Manage., 143, 13-26, doi:10.1016/S0378-1127(00)00501-6, 2001.

Waring, R. H. and Running, S. W.: Sapwood water storage: its contribution to transpiration and effect upon water conductance through the stems of old-growth Douglas-fir, Plant Cell Environ. 1, 131-140, doi:10.1111/j.1365-3040.1978.tb00754.x, 1978.

Waring, R. H., Whitehead D., and Jarvis, P. G.: The contribution of stored water to transpiration in Scots pine, Plant Cell Environ., 2, 309-317, doi:10.1111/j.1365-3040.1979.tb00085.x, 1979.

Williams, M., Malhi, Y., Nobre, A. D., Rastetter, E. B., Grace, J., and Pereira, M. G. P.: Seasonal variation in net carbon exchange and evapotranspiration in a Brazilian rain forest: a modelling analysis, Plant Cell Environ., 21, 953-968, doi:10.1046/j.13653040.1998.00339.x, 1998.

Yoder, B. J., Ryan, M. G., Waring, R. H., Schoettle, A. W., and Kaufmann, M. R.: Evidence of reduced photosynthetic rates in old trees, Forest Sci., 40, 513-527, 1994.

Yusop, Z., Chong, M. H., Garusu, G. J., and Ayob, K.: Estimation of evapotranspiration in oil palm catchments by short-term period water-budget method, Malaysian J. Civ. Eng., 20, 160-174, 2008.

Zeppel, M., Murray, B. R., Barton, C., and Eamus, D.: Seasonal responses of xylem sap velocity to VPD and solar radiation during drought in a stand of native trees in temperate Australia, Funct. Plant Biol., 31, 461-470, doi:10.1071/FP03220, 2004.

Zimmermann, M. H.: The monocotyledons: their evolution and comparative biology IV. Transport problems in arborescent monocotyledons, Q. Rev. Biol., 48, 314-321, doi:10.1086/407593, 1973. 